\title{
Classroom Culture and Its Importance in the Post Methods Era for Designing Pedagogy in Bangladesh
}

\author{
Md Khairul Bashar* \\ Lecturer, Shoheed Police Smrity College
}

\begin{abstract}
Classroom culture is an effective determinant for pedagogy to be effective in a particular context. In order to arrive at an appropriate pedagogy in the post methods era the classroom teachers, researchers and curriculum designers must investigate classroom culture. ELT practitioners of various countries are dissatisfied with the effectiveness of the borrowed pedagogy as the pedagogy has not been designed on the basis of the classroom culture as well as of the wider cultural and contextual realities of a second language learning situation. This dissatisfaction is severe in Bangladesh. So, it has been a must to reconstruct ELT practices. In this regard, some concepts of Post Method Pedagogy can help a lot for formulating a new process of learning English. The present study has been undertaken with a view to offering some new insights in the light of some aspects of Post Methods Pedagogy.
\end{abstract}

Definition of the Key Terms

Classroom Culture: The term "Classroom culture" has been used to mean what happens in the classroom between teachers and students, psychological state of teachers and learners and also the physical setting of the classroom.

Post Methods Era: The term 'Post Methods Era' has been used to mean the time after the period of method.

Variable:

The term refers everything related to the process of teaching and learning.

\section{Introduction}

For designing pedagogy of a particular context it is important to know what happens in the classroom between the teachers and students, and the physical setting of that classroom. This notion is particularly supported by the concepts of Post Method Pedagogy. Many researchers have thought it to be an alternative way for exceeding the boundaries of borrowed methods and approaches. For the last two decades various patterns of classroom instructions had been implemented to teach English in Bangladesh following the methods and approaches borrowed from native English speaking countries.

Those patterns of classroom instructions are contradictory to the classroom culture of Bangladesh. None of them has been designed on the basis of the native classroom experiences and contextual realities. No methods or approaches have brought expected results. So, if pedagogy is to be formulated, it needs to be constructed on the basis of the cultural and contextual realities of classroom by the ELT practitioners of this country.

\section{Theoretical Framework}

It has been supported by the theorists that it is necessary to develop teaching and learning methodologies that pay attention to classroom culture which is actually a reflection of outer social culture.

According to Schema theory (Barlet, 1932) Schema or background knowledge plays an important role in human learning process. If a child is accustomed with one cultural pattern or mode of teaching and learning, it exists and influences the child's learning throughout the life. Again the socio-cultural theory which is based on the works of L.S. Vygotsky (1978) maintains that psychological phenomena can be understood only by examining their genesis in a culturally specific activity. In this theory classroom and its interactions are considered as the legitimate domain of study for pedagogical decisions. Brew (1980) holds that, the way individuals respond to an educational program is influenced by the educational, cultural, social and employment milieu which they have experienced in the past.

According to structural view, language is regarded as a system of structurally related elements for encoding meanings. To learn a language one has to achieve mastery over structural elements of a language. In some contexts this view of language learning is fostered by the learners.

\section{Literature Review}

According to Holliday (1994), classroom teachers must investigate the classroom in order to arrive at appropriate methodologies. It is important to take "thick description" (p. 5) of the classroom situation which refers to depth analysis of the fragmented pictures of classroom. He has also suggested that when these small fragmented pictures are analyzed, understood and put together they will produce a bigger picture of particular setting the learners are concerned about. An ethnographic exploration of classroom is, therefore, vital in making sense of pedagogic practices. 
Shohiduallah (1997) also puts much emphasis on students' culture for teaching to be useful and effective. Citing research by Hatano and Miyake (1991), he provides three reasons for this view:

- It is important for setting up situation in the classroom which corresponds to learners' culture outside the classroom.

- It is necessary to design instruction based on prior knowledge of learners so that they can make connections and learn quickly with ease and pleasure.

- It is beneficial to know about learners' beliefs and values.

Shohidullah(2002), further clarifies:

Language teachers specially need to know the preferred learning styles and content expectations of their students. If students in a learning culture feel, for example, that second language learning is mainly a question of knowing an explicit detail the rules of grammar, then this has clearly an effect on their learning, no matter whether they are 'right or 'wrong' to hold on such views. (p.88)

Gardner (1989) argues that cultural beliefs influence the development of some attitudes which help in second language acquisition. Gardner (1979) states:

It is proposed that the social milieu gives rise to many expectations in the minds of the teachers and students concerning the entire second language acquisition tasks. (p.175)

An insight into students' characteristic learning style is necessary to develop appropriate language skills (James, 1980). James also holds that language teachers specially need to know the preferred learning style and content expectations of their students. Researchers, furthermore, suggest that classroom situation with its physical and emotional environment provides the formal context of language learning. According to Allwright (1988) learning situation may be viewed as learning opportunities. Skilbeck (1984) provides a curricular model that comes to be known as the situational model. This model has its basis in cultural analysis and it begins with an analysis of the institutional situation. Skilbeck (ibid) also says that all educational institutions should be a living educational environment; characterized by a definite pattern of relationships, aims, values, norms, procedures and roles.

Holliday (1994) considers an analysis of learning situation, which he calls "means analysis" important for meaningful and effective language program. Means analysis, according to Holliday and Cooke (1982), should involve:

An ongoing survey of the cultural, socio-political, logistical, administrative, psycho-pedagogic and methodological features of educational environment as it changes in the before and during the process of innovation.

Maley (1984) argues for an analysis of the constraints of the situation to provide the basis for designing meaningful language program. Pinxten (1991, p. 220) says that if a society-like situation is created in the classroom, learners will feel free from any cultural constraint and behave competently in the classroom. According to Saljo (1991), what occurs in the micro environment of the setting of learning is affected by larger contexts. Many studies now show that there is usually a productive learning environment when learners' beliefs, expectations and learning style preferences match with the activities and interactions in the classroom. If, on the other hand, there is a mismatch between these learners' factors and what actually happens in the classroom learners resist and consequently little or none is the learning outcome (Claxton and Ralston, 1978).

Thus, the researches and linguists think that the small classroom culture as well as the wider culture of a particular setting, therefore, has to be the main consideration while selecting classroom tasks, techniques, materials and tests.

\section{Culture and Psychological Buildup of the Learners}

Culture is an integral part of language teaching and learning. According to Keil (1989, 1 cited in Lantolf 1999), the concepts developed through culture can be thought of as networks of systematic beliefs about how the world is. It is argued that the values, norms and beliefs as well as the perceptions and experiences which a child acquires in the socialization process are his/her cultural profiles which have a very close relationship with learning. Shore (1996, 47 cited in Lantolf 1999) points out that concepts have their origins in two primary sources, personal mental models and cultural models. Thus culture shapes beliefs, attitudes, manners, and expectations etc. of the people of a particular society in a particular way.

According to Vosniadou (1991, p. 286), our mental life is a reflection of cultural reality. To understand what goes on inside the head of a man, he says, it is necessary to understand the cultural context where the man operates. Again researchers also suggest that process of early schooling imprinted on learners has a continuing effect on them and it affects teachers' and learners' goals and strategies and mode of learning.

Educational Culture of Bangladesh

As a distinctive nation, Bangladeshi people possess a specific culture which is different from any other countries of the world. In Bangladesh there is an impact of the patterns of earlier educational culture of Indian sub- 
continent. Depicting the educational culture of Bangladesh, Islam (2000) says, "asking too many questions to and entering into a debate or argument with the teachers is a sign of disrespect and teachers hardly appreciate it." Students owed the utmost reverence and obedience to teachers as the possessors and transmitters of knowledge.

Books are regarded here as an embodiment of knowledge, truth and sacredness. Learners believe in the ultimate authority of textbooks as in the subcontinent religious books were introduced first. There was too much importance on pronunciation. The slightest mistake in accent or pronunciation was regarded as a serious lapse. Each student was assigned to memorize some parts every day. That is why, "knowledge is seen as a monolithic entity, a finite, inflexible 'object', to be accepted whole and to be memorized and regurgitated" in our country. (Rahman, 1999).

For several centuries those processes of education continue to exist. Bangladeshi people have occupied those aspects of educational culture.

\section{Important Variables of Classroom Culture of Bangladesh}

From review of literature it has been found that it is necessary to pay serious attention to cultural factors of classrooms for developing methodologies. To expose the actual state of classroom culture the researcher has highlighted the following major variables of classroom culture.

\section{Psychological State of the Teachers and Learners}

Among many other variables psychological state of the teachers and learners includes:

a.Teachers' and learners' beliefs about language learning

b.Teachers' and learners' expectations about language learning

c.Previous experiences of the teachers and learners

a. Beliefs of the teachers and learners of Bangladesh are different from any other context of the world. Cotterrall (1995) argues that learners' beliefs regarding the different aspects of classroom culture determine their readiness for and acceptance or rejection of the ideas and practices of teaching learning theory. In our context students believe that a teacher is the source of all knowledge. They depend on the teachers for their learning. Some students think that their teachers should do all the things for their learning. Similarly they have respective beliefs regarding classroom interactions, classroom atmosphere and other aspects of classroom culture.

b. Learners' and teachers' expectations are influenced by their social and educational background. Spolsky (1989) expresses the view that a second language learner brings to language learning situation a set of notions about what is involved in the tasks. In Bangladesh, learners are expected to be respectful to their teachers, and teachers are expected to be strict, omniscient and caring. Students too expect that their teachers will teach them seriously and will behave with them in a dignified manner in the classroom.

c. Learning styles refers to the way learners like to learn a language. Bannai (1980) describes the cognitive learning styles of Asian students as field dependent. She claims that students' orientation toward group success and individual behaviors emphasize restraint, co-operation, and obedience to authority. According to Cortazzi, (1994, cited in Shohidullah, 1997) the oriental learning style is characterized by:

- Considering only one correct point of view

- Describing information without critical evaluation etc.

\section{Actual State of Affairs in the Process of Classroom Teaching and Learning}

To expose the actual state of classroom affairs we need to know the following two variables.

a. Mode of Feedback and Error Corrections

b. Interactional Patterns

a. In our context mode of feedback and error corrections are integral parts of language teaching and learning procedures. Usually teachers provide immediate feedback. Contexts like ours correction of errors is taken seriously. Learners are basically worried about pronunciation, not about fluency.

b. In a classroom there can be various patterns of interaction. Here learners do not participate in pair or group tasks. In our classes, unidirectional flow of information is noticed as teachers deliver lecture most of the time of the class period.

\section{Physical Setting of the Classroom}

Spolsky (1989) says that the physical situation in the classroom can both assist and impede learning. To know about the physical setting of the classroom we are to consider :

a. Class Size:

b. Teaching-Learning Aids

c. Seating Arrangement

a. Class size refers to the number of the students in a classroom. In our context almost all the classes are large. It is suggested that a large classroom is not suitable for interactive teaching and learning. At least, a 
large class is suitable for some teachers-students interactions.

b. Teaching learning aids refer to the equipments which are used for the purpose of teaching and learning. For developing or poor countries like ours board is the most common teaching learning aids. For different available aids different processes of teaching can be effective.

c. According Cohen and Manion (1977) careful attention to seating arrangements contributes more than any other aspects of classroom environment. In case of seating arrangement the researchers need to consider :

\section{- The position of teachers in the class and}

- Seating arrangement of the students.

In Bangladeshi classrooms teachers take a frontal position which gives the teachers an authoritative position and alienates him from the students. Students have fixed benches or desks arranged in long rows.

\section{Major Concepts of Post Method Pedagogy}

According to Kumaravadivelu (1994), the leading proponent of Post Method Pedagogy, no method or approach can be implemented in the purest form in the actual classroom because they are "not derived from classroom experience and experimentation but are artificially transplanted into the classroom and, as such, far removed from classroom reality" (ibid. p. 29). So "the notion that one method cannot be appropriate for every teacher and every learner in every time and every place" has been proved (Cattell, 2009, p. 59). Again it does not advocate for complete abandonment of the existing methods. In some cases it endorses any attempt on the part of the teachers to modify and adjust an established method to the realities of their local contexts. (Richards and Rodgers 2001, p. 251)

Post Method Pedagogy concentrates on the development of locally produced pedagogy by the local ELT practitioners based on the local classroom realities. To Kumaravadivelu (1994, p. 29), Post Method Pedagogy involves practitioners constructing classroom oriented theories of practice. Teachers are to formulate their own model or theories and develop procedures. Again it also suggests 'teacher's sense of plausibility' (Prabhu, 1990, cited in Kumaravadivelu, 1994). It means their subjective understanding of teaching they do. Thus, Post Method Pedagogy aims to empower teachers with knowledge, skill and autonomy.

Post Method pedagogy demands re-evaluating the roles of the learners, the teachers and the teacher educators. Kumaravadivelu (2001) considers learners, teachers and teachers' educators as co-explorers. The interaction between the teachers, educators and the prospective teachers should become dialogic as he mentions:

When, through a series of dialogic interactions, channels of communication between teacher educators and prospective teachers open up, when prospective teachers actively and freely use the linguistic, cultural, and pedagogic capital they bring with them, and when teacher educators use the student-teacher's values, beliefs, and knowledge as an integral part of the learning process, then the entire process of teacher education becomes reflective and rewarding (p. 552).

PMP also pleads that teachers will revise their theories, techniques or strategies. It will be a continuous process. Continually they will go on experimenting their teaching strategies. They will remain in one kind of action research. When the teachers will develop a set of teaching technique he then will bring little changes in respect of cultural variables. There is no scope of selecting final copy. They also need to keep eyes to the latest development in the field of language teaching and learning.

Teachers' training is of paramount importance in PMP. The proponents believe that no advice should be imposed rather teachers should be permitted to express their opinions. Teacher will share their views among themselves. Trainers can give some suggestions regarding how to develop their own strategies.

Kuranavadivelu (2001, p. 538) has suggested three parameters as the key points of PMP. In his parameter of particularity he suggests that pedagogy must be sensitive to "a particular group of teachers teaching a particular group of learners pursuing a particular set of goals within a particular institutional context embedded in a particular socio-cultural milieu" (p. 538). In his parameter of practicality he mentions that there should be a harmony between what the teachers of a particular context will theorize and what they will practice in the classroom. According to him a theory is meaningless unless it can be applied in practice. Teachers are to formulate theory while they are on the job.

Kumaravadivelu (ibid) has proposed that ten macro strategies. He, in Mac. 1, Maximize Learning Opportunities, views learning as a process of creating and utilizing learning opportunities. In another strategy, raising the consciousness of good language learners about various learning strategies and making the strategies explicit and systematic are described as important. It also supports that learners can raise cultural awareness by identifying the cultural knowledge learners bring to the classroom. In his Mac. 10 he urges for social relevance which refers to the need for teachers to be sensitive to societal, political, economic environment in which $\mathrm{L}_{2}$ learning and teaching takes place. Teaching, as his Mac. 10 suggests, makes little sense if it is not informed by social relevance.

Kumaravadivelu (1994) also clarifies that the strategic framework is general plan derived from theoretical, empirical and pedagogical knowledge. The macro strategies are considered as broad guidelines 
depending on which teachers can develop their own situation specific classroom techniques. He also suggests not following macro strategies if they are not considered suitable.

\section{A Synthesis of the Concepts of Post Method Pedagogy with the Actual State of classroom Culture}

So far the researcher has tried to discuss various aspects of classroom culture and important aspects of Post Method Pedagogy. Now the researcher is going to implement some effective aspects of Post Method Pedagogy considering the actual picture of classroom culture.

The proponents of PMP argue for formulating a new set of strategies and procedures for language teaching based on cultural realities of classroom. PMP also values experiences and knowledge of the ELT practitioners. The very classroom culture of Bangladesh suggests the idea that it is obligatory to design pedagogy by the local ELT practitioners considering the classroom realities to make the pedagogy effective.

According to PMP, teachers are to play dominant role for exploration of pedagogy. They have to shoulder upon the main responsibility of pedagogy. They have to theorize from their practice. They also need to shape and manage classroom learning. This role is also suggested by the classroom culture of Bangladesh. Here the teachers are accustomed to take responsibility of learning. Teachers want students to be dependent on them and learners like to depend on teachers for everything. The beliefs and expectations of both the groups and learning styles preferences of the learners support this kind of role of the teachers.

Post Method Pedagogy suggests considering every classroom as particular for pursuing a particular set of goals within the particular socio cultural context. At this point the total Bangladesh can be taken as a particular context. It is true that overall classroom culture of the whole country is almost the same. Pursuing a particular set of goals within the particular social cultural context of Bangladesh, a group of teachers can set teaching learning practices for the learners of Bangladesh.

Learners have to be made cautious about learning styles preferences, about the importance of beliefs and experiences. This idea is also highlighted by PMP. For the learners their consciousness can be fruitful. It is a must to take suggestions from them for pedagogic exploration. Raising learners' consciousness is also important for Bangladeshi context.

In PMP teachers educators are to promote the students' and teachers' values, beliefs for the entire process of teachers' education to be rewarding. The present realities of classroom demand evaluation and promotion of teachers' and learners' values, beliefs and expectations.

It is seen that learners want to learn knowing the grammatical rules which is suggested in one of the strategies of PMP. Furthermore, practice of all basic skills of language is very important for Bangladesh. PMP is also in favor of developing basic skills and their sub skills.

Teachers' training is of paramount importance in PMP. Not only the teachers but also the learners can be trained. In our context it is found that teachers are not trained at all. Training is the most important issue than any other factors of language teaching and learning at least for Bangladesh.

Some proponents think that PMP does not mean the end of methods rather it involves an understanding of the limitations of the concept of method and a desire to go beyond those limitations. Pedagogy designers of Bangladesh can utilize this concept of PMP by selecting fruitful concepts from a number of methods.

\section{Conclusion}

Pedagogy designers have to consider the present psychological state of the teachers and learners and accept the present physical setting of the classroom at the time of designing pedagogy. The present realties of classroom culture require a utilization of:

- The available facilities

- Interactional realities prevailing in the classroom and

- The present psychological condition of the learners and teachers.

In the light of the research following conclusions can be drawn as recommendations for pedagogic exploration.

\section{General Recommendation}

- Taking whole country as a particular context the practitioners need to construct a central methodology of learning considering the classroom realities. This would be suitable for our context as all the teachers don't have enough competence.

- A group of nationally selected teachers from various universities and different colleges of the country need to shoulder upon the responsibilities for implementing pedagogy. Those teachers can produce pedagogy based the suggestions of other teachers and learners who spend much time in the classroom.

- Sense of plausibility of the selected group of teachers, not all of the teachers, should be used to theorize teaching methodologies. They need to evaluate the beliefs, experiences, expectations and preferences of the teachers and learners. They should also involve learners to some extent in designing pedagogy.

- The selected group of teachers should keep eyes to the latest development in the arena of language teaching and learning so that they can keep pace with the international community. 
- At the end of every session, individual teachers of the country can be asked to make some suggestions. Based on the ongoing feedback of the classroom teachers' suggestions the pedagogy needs to be continually modified, expanded and enriched step by step over some years. Following the process they will be able to find out most effective way of language teaching after some years.

\section{Recommendations for Syllabus and Material Design}

For Bangladesh it is important to design a syllabus. A syllabus complemented by teacher-controlled tasks and activities and grammar based items would provide the ideal solution for the students. The proposition of Huda can bring positive results in this regard. Huda (2004. p. 123\&126) suggests "in a context like Bangladesh the main approach to learning English should not be through communication, but through learning its system".

At the time of designing textbook there should have profusion of individual tasks in the textbook. Life styles, values, norms and customs of Bangladeshi culture and society should be depicted enormously in the texts so that learners feel familiar with those things and therefore comfortably understand the texts. Social relevance of the contents and topics is also necessary.

\section{Recommendation for Teachers' and Students' Roles}

Teachers need to play dominant roles. They should guide learning, select contents, materials and methods taking the interest of the learners. After analyzing various aspects of the social and educational culture of Bangladesh, Rahman (1999) rightly remarks that for ELT innovation in Bangladesh a "synthesis" model embracing different models as deemed appropriate can be formulated. Teachers have to select contents and materials in consultation with students. As language is a skill-based subject the role of the learners has to be made more engaging in doing tasks and activities for developing their basic skills.

\section{Recommendation for Interactional Patterns}

There can be eclectic style including lecture method and activities under teacher control. Open ended discussions in whole class sessions under teachers' control can be another fruitful activity for learners' engagement in learning process. Since teachers and students like error corrections, there should be some error corrections in the language classroom. Teachers should provide feedback in whole sessions on students performance.

\section{Recommendation for Trainings}

Paramount importance should be given on teachers' and learners' training for developing the knowledge and skills necessary to construct their own pedagogy. The selected group of teachers needs to train the teachers of different districts and take recommendations for classroom procedures. There can be some leaner training to orient them with the roles for their leaning .

To sum up, the pedagogy designer following the recommendations suggested above can devise an effective methodology for the learners of Bangladesh.Thus the present researcher believes that this dissertation can bring an overall change in the teaching learning of English in Bangladesh.

\section{BIBLIOGRAPHY}

Allwright, D. (1988). Observation in the Language Classroom. London: Longman.

Bannai, Hideko. (1980). Socio-Cultural Influence on the Communication of Asian ESL Students, In On TESOL, Washington, S.C. TESOL.

Barlet,F.C.(1932). Remembering.Cambridge: Cambridge University Press.

Brew, Angella. (1980). Responses of Overseas Students to Differing Teaching Styles. ELT Document- 109. London: The British Council.

Cattell, Allisan. G. (2009). Re-evaluating Communicative Language Teaching: Wittgenstes and Postmethod Pedagogy. M.A. Thesis presented to the University of Waterloo in German. Waterloo, Canada.

Claxton, C . and Ralston,Y. (1978). Learning Styles: Their Impact on Teaching and Administration, ASHERERIC Report No.4

Cohen, L. and Mannion, L. (1977). A Guide to the Teaching Practice. London:

Cortazi, Martin.(1994). Cultural and Educational Expectations in the Language Classroom, ELT Documents; 132.

Cotterral, Sara. (1995). Readiness For Autonomy: Investigating learner Beliefs, System, 23/2, 195-205.

Gardner, R. C. (1979). Social Psychological Aspects of Second Language Acquisition. In Giles, H and Clair, R St. (eds.) Language and Social Psychology. Oxford: Basil Blackwell.

Gardner, R. C. (1989). The Socio-educational Model of Second Language Learning: Assumptions, Fuideings, and Issues, Language Learning, 38/1: 101-125.

Hatano, Giyoo and Miyake, Nasmi. (1991). What Does a Cultural Approach Offer to Research on Learning, Learning and Instruction, Vol. 1: 273-28.

Holliday, A. (1994). Student Culture and English Language Education: An Interactional Perspectives, Language culture and Curriculum, vol 7, No.2: 125-143.

Holliday, A. (1994). Appropriate Methodology and Social Context. Cambridge: Cambridge University Press. Holliday, A. \& Cooke, T.( 1982). An Ecological Approach to Esp. In A Waters (ed.) Lancaster Practical Papers 
and English language Education, 5 (pp. 124-143) Oxford: Pergamon Press.

Huda, Mohammad Emdadul. (2004). Culture Sensitive Materials for English Language Teaching in Bangladesh. Unpublished Ph. D. Dissertation, Institute of Bangladesh Studies (18\$), University of Rajshahi, Bangladesh.

Islam, J. (2000). The Concept of Learners Autonomy and Its Feasibility in Bangladesh. In ELT 2000: Directions and Orientations (Proceedings of a Seminar held at the Department of English, Rajshahi University, January 30-31, 2000, pp. 29-36). Rajshahi: Rajshahi University.

James, Kenneth. (1980). Seminer Overview, ELT Document-109: Study Modes of Academic Development of Overseas Student. London: The British Council.

Keil, F. C. (1989). Concepts, Kinds, and Cognitive Development.

Kumaravadivelu, B. (1994). The Postmethod Condition: (E)merging Strategies for Second/ Foreign Language Teaching. TESOL Quarterly28, 27-48.

Kumaravadivelu, B.(2001). Toward a Postmethod Pedagogy. TESOL Quarterly, 35(4), 537-560.

Lantolf, J. P. (1999). Second Culture Acquisition: Cognitive Consideration. In E. Hinkel (Ed.), Culture in Second language Teaching and Learning (pp. 28-46). Cambridge: Cambridge University Press.

Maley, A. (1984). Constraints Based Syllabuses. In Read, J (1984).Trends in language Syllabus Design, Singapore. RELC Anthology, 13.

Pinxten, R. K. 1991. Geomatry, Education and Culture. Learning and Instruction,vol.1: 217-227.

Prabhu, N. S. (1990). There is no best method -why? TESOL Quarterly, 24, 161-176.

Rahman, A. (1999). ELT Innovation and Cultural Change: A Bangladeshi Perspective. In T. Hunter (Ed.), Collected Papers of International Conference on National and Regional Issues in English Language Teaching: International Perspectives (pp. 235-254), held at the British Council, Dhaka from January 31 to February 2, 1999.

Richards, J. C. \& Rodgers, T.S. (2001). Approaches and Methods in Language Teaching. Cambridge: Cambridge University Press.

Saljo, R. 1991. Introduction: Culture and Learning. Learning and Introduction, 1, 179-185.

Shahidullah, M. (1997). Teaching-Learning Culture in Bangladesh and Recent ELT Theories: Confrontation and Contradiction. Unpublished Ph.D. Dissertation, University of Pune, India.

Shohidullah, M.( 2002). Developments in Learning Theories and the Concept of Appropriate ELT Pedagogy. Panini: NSU Studies in Language \& Literature. Vol. 1:79-98.

Silkbeck, M (1984). School Based Curriculum Development. London: Harper and Row.

Shore, B. (1996). Culture in Mind: Cognition, Culture and the Problem of Meaning. Oxford: Oxford University Press.

Spolsky, Bernard. (1989). Condition for Second Language Learning. Oxford: Oxford University Press.

Vosniadou, S. (1991).Are We Ready for a Psychology of Learning and Culture? Learning and Instruction, 1, 283-287.

Vygotsky, L. S. (1978). Mind in Society. Cambridge Mass: Harvard University Press. 